\title{
Shaping of the intra- municipal relations in the contemporary local government on the city of Poznan example
}

Prof. Piotr Bartkowiak, Ph.D., D.Sc.

Poznań University of Economics and Business

Faculty of Management Marianna Krzakiewicz, M.Sc. Poznań University of Economics and Business Faculty of Management

\section{Introduction}

Theimportanceofcitiesascentresofeconomic development is increasing worldwide. This is the reason skilful management is required from city authorities, coupled with carefully prepared marketing plans. When cautiously tailored, place marketing is a tool that can serve city authorities to promote, and strengthen their city's position among other cities.

The aim of this paper is to assess whether practices of shaping the intra-municipal relations can be treated as a tool of territorial marketing mix, and an attempt to introduce it as a tool of communicating with the city's external audience is made. Intra-municipal relations' role in Poznan's place marketing strategy is determined, the examples of the city's intra-municipal relations are recognised, and an effort to evaluate their influence on the city's external audience is made.

\section{Building of the intra-municipal relations in territorial marketing}

The term place marketing, also known as territorial marketing, marketing of places, 
government marketing, regional marketing, and city-marketing (Szromnik 2011, p. 19) pertains to all techniques and tools focused on building and developing the attractiveness of a given region. Place marketing might be perceived as a management approach that encloses a unique strategy created and implemented via specific tools of territorial marketing mix (Amajid et al., 2017, pp. 37-40), which are aimed at creating a city that meets its needs, and attracts residents, and visitors (Szromnik 2016, p. 34).

The concept of territorial marketing is based on the condition that a place, just as any other product can be marketed: that is, sold, bought, and promoted (Kamiński 2011, pp. 5-6), and territorial marketing serves as a tool of management and development of the city's value. This is empowered by the promotion of goods and services available in the city, and by work and other activities of the people and enterprises operating therein (Gafurov et al., 2013, pp. 19-20).

In its recipient's minds, place marketing is designed to create an exceptional image of a territory, which should be perceived as different, and better than other territories competing with it (Wyrwa 2015, p. 19). A city has limited resources at its disposal to achieve this goal, which is why a carefully designed strategy plays a key role in its success. Such a strategy aims at selling a place by presenting it from its most appealing side and is manifested through place marketing (Zbuchea 2014, p. 135). Cities use territorial marketing to communicate with other cities, its own citizens, and businesses operating therein, and inform them about the originality of the city. It forms the views and opinions of the receivers of its message in a way that is most convenient for the city (the sender) (Szromnik 2016, p. 35). Therefore, territorial marketing is a form of communication between a city and its external audience that becomes of a great significance. It enables authorities to directly interact with the people in a less official, and therefore more approachable manner.

While attempting to define intra-municipal relations' role for territorial marketing one should begin with the explanation of the concept of soft power coined by Joseph Nye (1990, pp. 1-2). Nye described it as the power of attraction to one's ideas, related to the way in which a country acts (Melissen 2005, pp. 115-116), to its foreign policy, its culture and political values (Allison 2008, p. 102). Cities, just like countries, are more, or less affluent when it comes to soft power resources, which are essential for increasing their competitiveness. Building intra-municipal relations is a method to increase a city's soft power (Nakamura 2013, p. 2), and win the essential support of its outside audience (Ross 2003, pp. 22-23). How the city is perceived from the outside is vital for 
its future success, so it should be ensured that external actors are well-aware of what it offers and its potential. In intra-municipal relations, there are non-governmental organisations, specialists, and private people involved, which empower building and sustaining long term relationships (Snow 2010, pp. 91-92).

Building of inter-municipal relations is a part of territorial marketing, aimed at forming the external audience's attitudes toward the city, which can be achieved directly by influencing the visitors of a place, and indirectly by supervising contacts between the internal, and the external audiences (figure 1). As a result, a specific image of a place is formed and created.

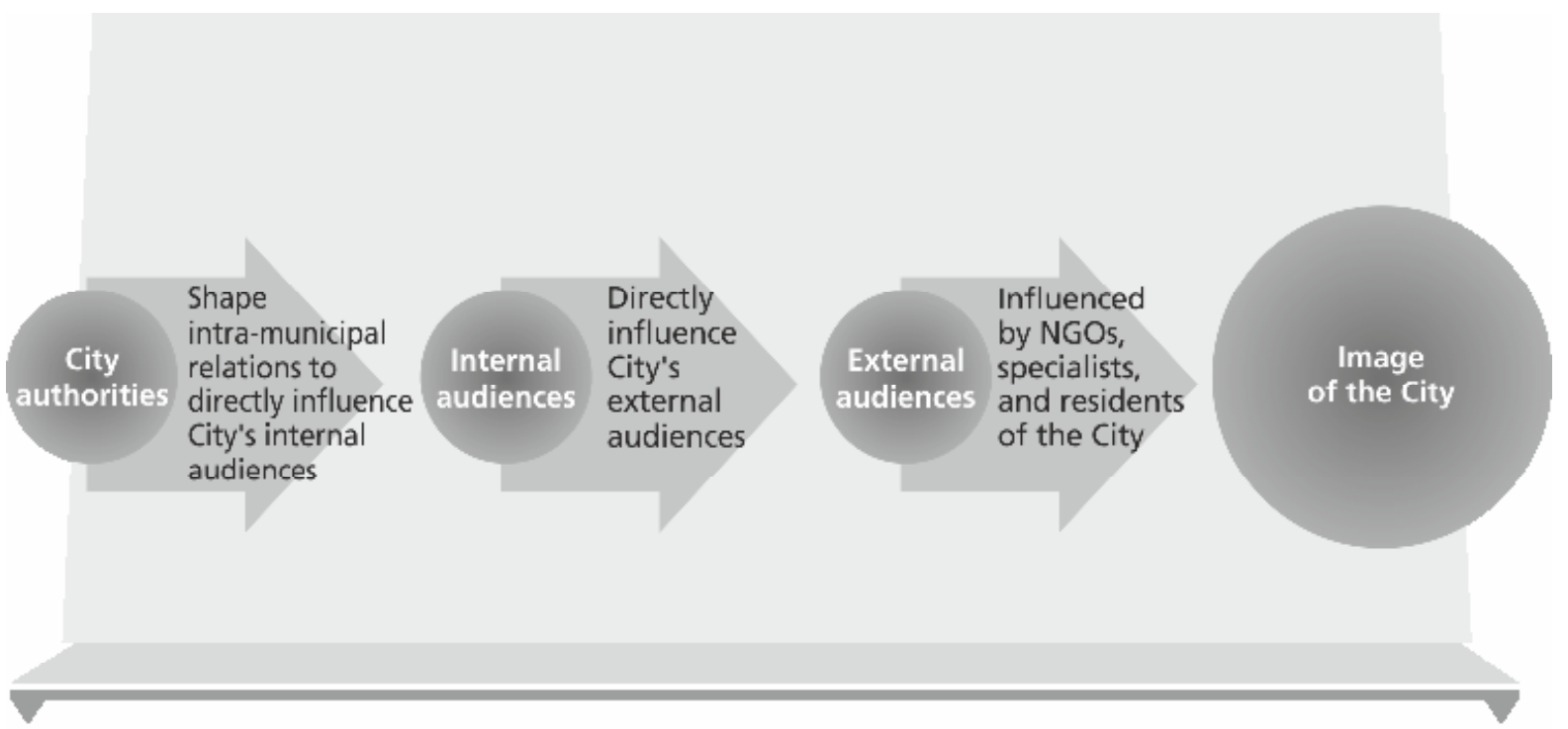

Figure 1. Creating the image of a city by building its intra-municipal relations

Source: own elaboration

In this age of new technologies, the Internet, and social media, intra-municipal relations' importance is increasing daily. Groups of people influenced by these modes of communication network with others, create platforms with common views, exchange ideas, and communicate their attitudes (Hayden et al., 2013, pp. 1624-1627). These social phenomena are ready to be used by cities' authorities to effectively communicate their message, as "it is not what is said that counts, it is what is heard" (Ross 2003, p. 25). 


\section{The main challenges that Poznan is facing in the context of intra- governmental relations}

Quality of life is becoming of key importance when evaluating a city's competitiveness (Morais et al., 2011, p. 188). A city's quality of life may be determined by such dimensions as its ecological environment, sustainable available transport, the quality of public services and housing, and the diversity of jobs offered (City of Poznan 2017, pp. 2-5). Increasing Poznan's quality of life has become a fundamental challenge for its city authorities, as $60.4 \%$ of the population was content or very content with life in the city in 2015, which was less than in the years 2011, and 2013 (63,9\% and 65,6\% respectively) (Czapiński, Panek 2015, p. 201).

A major issue, which directly influences a city's quality of life, and is steadily gaining in importance, is ecology. Shaping of Poznan intra-municipal relations should aim at spreading good practices observed in other cities where concepts of being a green city, and ecological transport are gaining more attention. Some of the ideas which have been put forth are of creating spaces destined for growing vegetables (as in Andernach, Germany (Guinness, 2014), growing orchards (there are fruits harvested in Berlin (von Hoffen and Säumel 2014), and founding green roof tops as in Vienna in Austria (Green roofs in Vienna, Austria 2015). Regarding the number of cars in the city, there are two major problems that need to be dealt with: first is the traffic problem, and second, the total amount of available parking spaces. There should also be more investment made for green areas in the city, and increased promotion of citizen's pro-ecological behaviour (City of Poznan 2017, p. 20 and pp. 24-25).

Thanks to the growing availability of new technologies, it has become easier for people to gain information, to network with each other, and the distance between common citizens and the city government has become smaller. These phenomena result in a growing eagerness (and possibility!) for people to participate in creation of the city's reality. Therefore, there is a need for city authorities to make themselves accessible, to publicly involve residents in their actions, and to make them feel their being heard is important. Another advantage would be an increase of the quality of life in a city, as more institutions and organizations would be involved in a dialogue aimed at providing new, better solutions for the city. (PricewaterhouseCoopers 2005, pp. 3-5, 40-49, 64-65)

Due to the ageing of society, it is vital for cities to consider special needs of people over fifty-five years old. Along with the phenomena of depopulation, it is anticipated that there will be $20 \%$ less people living in Poznan in 2050

PIOTR BARTKOWIAK

MARIANNA KRZAKIEWICZ 
(with those leaving mostly between the ages of thirty and thirty-nine years), and it is expected there will be two times more people over sixty-five years old. It is predicted there will also be two times less people in schools and of university age. According to the demographic forecast for the years 2011-2035 prepared by the Main Statistical Office on the $11^{\text {th }}$ July 2011, post-working-age population is the only group in which population growth is expected (by 19\%) (Central Statistical Office 2011). As the society grows older (Poznan Statistical Bulletin 2016; Poznan Statistical Bulletin 2017; Ross, 2003), there is a pressing need to make the city more age-friendly, and to offer senior citizens a high quality of life. Therefore, place marketing strategy should highlight the fact that Poznan is a city where everybody has the same opportunities regardless of age. By shaping the intra-municipal relations, the city should encourage older adults to continue their professional activity, and develop entrepreneurial skills. Due to the accessibility of new technologies, people of post-working-age can connect with younger people, network with them, and share their experience. Nevertheless, senior residents might be distrustful towards new technologies, which is a barrier crucial to be overcome. Research proves that positive attitudes toward Internet technologies constitute the most important predictor of social well-being, and appears to be a significant predictor for psychological well-being as well (Zambianchi, Carelli 2016, pp. 381-385). There is a broad field of opportunity for territorial marketing to increase the acceptance of new technologies among senior citizens and therefore reduce the distance between them and the younger generation who could benefit from their experience. This can be accomplished, for example by education programs led by the local communities' leaders.

The above challenges are important markers for achieving the type of quality of life the city's residents desire, and therefore key indicators of the city's prosperity. It is highly important for city administrators to consider residents' satisfaction with their city, as positive reactions can lead to word-of-mouth communications with their acquaintances outside the city. Taecharungroj (2016, pp. 343) describes this social advocacy as a behaviour, which shapes the intra-municipal relations: When a city's residents act as its ambassadors, the encounters between them and other potential customers of the city can become important touch points that promote the city. There are many possible forms of city ambassador behaviours, such as online, offline, direct and indirect communications. Residents can recommend the city to their friends or relatives during their visits or through social media. Street vendors and local businesses can say good things about the city to international tourists. Foreign expatriates who reside in the city might encourage their companies to invest more in that city.

Shaping of the intra-municipal relations in the contemporary local government on the city of Poznan example 
City authorities should do their best to keep the residents' satisfaction, and the city's quality of life on a high level, as this is proven to positively influence city ambassadorship behaviour (Taecharungroj 2016, p. 1 and pp. 343-346). Such unofficial communication strengthens more formal communications from the city (Kavaratzis 2004, p. 69), and has the potential to fill any gaps left by a city's formal communications via their promotional message (Taecharungroj 2016, p. 343). Taecharungroj (2016, p. 344) also distinguishes city citizenship behaviours that are positively affected by resident satisfaction, and affect a city's marketing settings. Citizenship behaviours occur when residents actively wish to make their city a better place by helping other people, or participating in city events. By assisting people who exhibit such behaviour, properly shaped intra-municipal relations may assure them that values held by the city are in line with their own, and that their needs, lifestyles, and feelings are being taken into consideration when creating services and public spaces. If they believe this, they are likely to share their positive opinions with external actors, therefore making territorial marketing practices successful in influencing external audiences which is necessary to fulfil the city's marketing strategy. Territorial marketing allows city managers to communicate directly with people by emphasising unofficial means of communication such as those with influence and social media, to create an image of a city that cares for them. However, it must be remembered that any information aired by a city must be consistent with the city's actual state of affairs as "credibility is the sine qua non of (...) communication" (Ross 2003, p. 24).

\section{Intra-municipal relations of Poznan to increase its competitiveness by making it a better place to live}

Each challenge that Poznan now faces should be met by the city's place marketing practices. To face the challenge of ageing of the society, its role is to create the image of an age-friendly city; when dealing with ecological factors - an image of an eco-friendly place should be created; as far as participation issues, an image should be presented of a city where everyone is listened to and citizens have the possibility to make an impact on the city's development. In fact, each of these aspects contribute to the overall quality of life in a city.

Poznan is well known for its International Fair, where an exchange of knowledge and ideas takes place between the citizens of Poznan, and visitors coming from all parts of Poland, as well as abroad. On one hand, the Poznan 
International Fair presents a central hub for information and innovation, on the other, it gives the city the possibility to promote its image in the visitors' minds. Developing a good perception of the city's regular fairs helps certify the city's efforts to promote the idea of Poznan being an ideal place to live and visit.

\subsection{Ageing of the society}

"Viva Seniorzy!" is a fair focused on the quality of life of senior citizens surrounding three main factors: activity, health, and prophylaxis. The fair's last edition took place on 12-13 May 2017, and was organised in a cooperation between the city of Poznan, and the Poznan International Fair (Dlaczego warto? 2018). During the event, visitors had the possibility to learn about: health, work, education, travels, sport, beauty and lifestyle, passions, new technologies and media, and law and finance. Each of these areas was carefully designed to meet the needs of people over 50 years old.

Poznan provides its senior citizens with institutions such as the City Senior Council (Miejska Rada Seniorów), initiated by the City Board in 2007, which ensures senior citizens the opportunity to influence their community, as well as other specific issues related to the oldest generation. Another institution created in 2009 (Poznan City Council 2009) by the initiative of the City Senior Council, and the City of Poznan, is the Centre of Senior Initiatives (Centrum Inicjatyw Senioralnych), which is a city administration unit, one of the first of its kind in Poland. The Centre provides the opportunity for senior to meet and gain inspiration from their knowledge and experience, as well as to support them in increasing their quality of life and help them to live actively and participate in the city life. The Centre encourages seniors to get out of their homes, and enjoy their lives by providing them with the "Information Point $60+$ " - a space designed to offer people over 60 years old information about possible initiatives.

Poznan is also one of three cities participating in the international program, Age-Friendly Cities (Lehmann, 2017). There are plenty of other initiatives available aimed at making the lives of senior citizens better, information about which is available on the Internet (e.g. mrs.poznan.pl), in local Culture Centres (e.g. Jeżyckie Centrum Kultury), through various foundations (e.g. Fundacja TESPIS scena na piętrze), festivals (e.g. theatrical festival KONTEKSTY), and during fairs.

Poznan VIVA Senior is the first program in Poland offering the elderly a free taxi service if they need to get to a doctor, or go to a town council; as well as the possibility to order a book from a library, or help if they are in need of a handy-

Shaping of the intra-municipal relations

in the contemporary local government on the city of Poznan example 
man service (Frydryszek 2017). Another initiative is an educational platform for senior citizens run by the Poznan Supercomputer - Network Centre - a Moodle platform: 'Poznan e-senior' ('Poznański e-senior'). The program provides plenty of educational materials accessible for those authorised to do so by the Poznan Senior Council, and Universities of the Third Age (Szkutnik 2017). Another advantage coming from the 'Poznan e-senior' programme is preventing cyber exclusion of senior citizens, and therefore increasing their possibilities of participating in life of their society.

\subsection{Ecology}

Ecology is a great challenge faced by Poznan's modern territorial marketing practices. On the twenty-sixth of September 2017, a new Programme of Environment Protection for the City of Poznan for years 2017-2020 with a perspective to 2024 ("Program ochrony środowiska dla miasta Poznania na lata 2017-2020 z perspektywą do 2024 roku») was accepted by the Poznan City Council. The content of the document was submitted for local social consultancy, which has become a practice frequently used by the city of Poznan. Another example was a citizen's consultancy effort concerning the Anti-smog resolution that took place between the thirteenth of September, and the forth of October 2017, and which gave the residents the possibility to participate in creating the city's reality. Poznan International Fairs are one of the city's most influential events, during which the city has a possibility to present itself as being eco-friendly and sustainable. Pol-Eco System is one of the biggest, and most important events of this type in Poland, and in fact in all Middle-East Europe. Pol-Eco System is especially useful for shaping the intra-municipal relations, as it is open to a wide audience, and aims at reaching local residents. The fair gave Poznan the possibility to prove its concern about the condition of the natural environment to its own citizens, as well as visitors from other parts of Europe.

To update residents about the current ecological initiatives in the city, Poznan publishes the Ecological Poznan Bulletin. In the latest $\left(13^{\text {th }}\right)$ edition (Publication on 01.11.2017) there was information about the Programme of Environment Protection, a bicycle rally alongside the Bogdanka river, and the $6^{\text {th }}$ edition of the Ecodriving for the safety Poznan action. By overseeing this latest project the city aims at building and supporting its eco-friendly image by increasing the proportion of sustainable transport in the city (Ecodriving bezpiecznego Poznania 2017). Another attempt to make transport in the city eco-friendlier is by offering the Poznan City Bike service. The number of bicycle stations 
is constantly increasing, which itself confirms the city's sustainability efforts. What is more, there is a system of bicycle paths in Poznan, and a map of them published by the Administration of Municipal Roads (Zarząd Dróg Miejskich), which facilitates the everyday enjoyment of bicycles. To encourage people to use bicycles, there are various bicycle-focused events organised in Poznan, one of which is a Bicycle Rally following the Strzeszynek Lake which is aimed at young riders of primary school age, and is connected with educational subevents related to ecology issues. On one hand, the city reaches children, on the other it has a possibility to meet their parents, which makes these kinds of events widely popular and influential.

Another area of ecology that needs to be considered by Poznan's marketing strategy, are sustainable energy sources. There are several intensified actions aimed at providing pro-ecological initiatives, processes and technologies, which convey the need for increasing the percentage of renewable energy utilised by the city. A significant territorial marketing practice focusing on this topic was organised for the first time in 2016, called Poznan Energy Day (Poznańskie Dzień Energii) that focuses on increasing the local community's energy awareness in terms of rational and economical energy management, improvement of energy effectiveness, and usage of renewable energy sources. The event appears as a part of an EU initiative - the international Sustainable Energy Week conference. This event included an art contest for upper and primary schools in Poznan, as well as an organized educational picnic for whole families. Since the event has a Facebook profile, it is possible to directly reach many people which contributes to its success in attracting a broad audience of participants, and helps influence their awareness of how important it is to use energy in a sustainable manner.

\section{Conclusions}

The significance of intra-municipal relations in the city is gaining more importance with the development of technological solutions and an emphasis on social media, and increasing its availability among senior citizens as well. Nowadays, it is not only an opportunity for the city's authorities to directly reach and influence their residents, but has become the official's duty. Citizens expect the city to communicate with them directly, they want to be informed, and to participate in the life of the city. Therefore, intra-municipal relations should be taken into careful consideration when creating the city's marketing strategy.

Shaping of the intra-municipal relations

in the contemporary local government on the city of Poznan example 
There are different approaches to the process of shaping the intra-municipal relations in the City of Poznan, and can target different groups of city residents. What is more, besides being effective, the practices of building the intramunicipal relations are relatively more affordable for the city, as they are cheaper than traditional campaigns. This becomes more visible when one considers Poznan's expenses on promotion dropped from 3,5 billion polish zloty in 2016 to 3,4 billion zloty in 2017 (Stępowski, 2017) following an emphasis placed on jobs for those involved in social influence and a number of specific actions taken on the Internet.

Naturally, there are shortcomings of practices of building the intra-municipal relations for the city of Poznan. First, even though they are more available, they do not reach all citizens, as do some traditional campaign methods. Oftentimes it is required for the targeted audience to actively search for the information they seek. Furthermore, due to the still existing problem of cyber exclusion of senior citizens it is rarely possible to reach them through the Internet. Therefore, non-traditional channels of communication like local influencers, and local community centres should be used more effectively, to acquire more residents in groups of their influence.

\section{Summary}

Shaping of the intra-municipal relations in the contemporary local government on the city of Poznan example

The main objective of this article is to evaluate the significance of forming the intra-municipal relations in relation to place marketing, based on the example of the Polish city of Poznan. Different conceptions of place marketing, and intra-municipal relations are defined, their mutual correlation aimed towards increasing a city's value is explained, and intra-municipal relations are illustrated. Poznan was chosen due to the preparatory cooperation which took place between the city, and its citizens. It is explained how Poznan's authorities incorporate practices of shaping the intra-municipal relations as a place marketing practice, for facing the city's important challenges such as: ageing of the society, ecological issues, the need for public participation, as well as the importance of maintaining a high quality of life for its citizens. The conclusion is drawn, that such marketing efforts for dealing with these issues do in fact have the joint goal of increasing the quality of life of all the 
residents of the city and that these practices are a recognised part of place marketing for the city of Poznan.

Keywords: relations, territorial self-government, territorial marketing, living standards of residents.

\section{Streszczenie}

Kształtowanie relacji wewnątrzgminnych we współczesnym samorządzie terytorialnym na przykładzie Miasta Poznania Zasadniczym celem opracowania jest ocena kształtowania relacji wewnątrzgminnych, na przykładzie Miasta Poznań, w kontekście marketingu terytorialnego. W materiale podjęto próbę zdefiniowania koncepcji marketingu terytorialnego, a także wyjaśnienia wzajemnych korelacji między marketingiem terytorialnym i zależnościami wewnątrzgminnymi w dążeniu do podniesienia roli i znaczenia, a w konsekwencji wartości podstawowej jednostki samorządu terytorialnego. Wybór Poznania wiąże się z faktem, że w Mieście zaczyna współcześnie dochodzić do kooperacji pomiędzy władzami samorządowymi, a jego mieszkańcami. W przeprowadzonej analizie autorzy podjęli się wyjaśnienia kształtowania przedmiotowych relacji w odniesieniu do starzenia się społeczeństwa, kwestii ekologicznych, potrzebie partycypacji społecznej obywateli, a także potrzebie zapewnienia wysokiego poziomu życia mieszkańcom. Konkluzją jest stwierdzenie, że kształtowane przez Miasto Poznań relacje wewnątrzgminne, mimo niekiedy swoich wad, mają wspólny cel, a mianowicie podniesienie poziomu życia wszystkich mieszkańców

\section{Słowa}

kluczowe: relacje, samorzad terytorialny, marketing terytorialny, poziom życia mieszkańców.

JEL

Classification: L38, R 11

\section{References}

1. Allison A. (2008), The Attractions of the J-Wave for American Youth, [in:] Y. Watanabe \& D. McConnell (Eds.), Soft power superpowers: cultural and 
national assets of the Japanese and the United States, M.E. Sharpe Inc., New York, p. 102.

2. Amajid G., Souaf M., El Wazani Y. (2017), Territorial Marketing Toolbox, an operational tool for territorial mix formalization, World Scientific News (65), pp. 37-58.

3. Biuletyn Ekologiczny Poznań No. 13 (2017), www.poznan.pl/mim/ newsletter/news,1128,27563/ biuletyn-ekologiczny-poznan-nr-13,111571. html (12.02.2018 - access date).

4. Central Statistical Office, Prognoza demograficzna do 2035 roku, Poznań $i$ powiat poznański, www.sip.geopoz.pl/data/analizy/prognozy_ demograficzne/indeks.php (11.07.2011 - access date).

5. Cities of the future. Global competition, local leadership (2005), Price Waterhouse Coopers, London.

6. City of Poznan (2017), Strategia Rozwoju Miasta Poznania 2020+, Rada Miasta Poznania, Poznań.

7. Czapiński J., Panek T. V. (2015), Social Diagnosis 2015, Objective and Subjective Quality of Life in Poland, Contemporary Economics. Quarterly of University of Finance and Management in Warsaw, 9 (4).

8. Ecodriving bezpiecznego Poznania 2017, http://www.poznan.pl/mim/ wos/news/ecodriving-bezpiecznego-poznania-2017,108899.html (12.02.2018 - access date).

9. Frydryszek P. (2017), Poznań dla seniorów, http:/ / mrs.poznan.pl/poznandla-seniorow / (27.10.2017 - access date).

10. Gafurov I., Bagautdinova N., Novenkova A., Kalenskaya N. (2013), Territorial marketing as successful strategy for regional development. The case of Russia, 3rd Annual International Conference on Qualitative and Quantification Economic Research, Bangkok: Global Science \& Technology Forum, pp. 18-23.

11. Green roofs in Vienna, Austria (2015), Office International de l'Eau, http:// nwrm.eu/case-study/green-roofs-vienna-austria (12.02.2018 - access date).

12. Guinness B., Welcome to Andernach, Germany's edible city. Retrieved from The Telegraph, http://www.telegraph.co.uk/gardening/ gardenprojects/10951813/Welcome-to-Andernach-Germanys-ediblecity.html (08.07.2014 - access date).

13. Hayden C., Waisanen D., Osipova Y. (2013), Facilitating the Conversation: The 2012 U.S. Presidential Election and Public Diplomacy Through Social Media, American Behavioral Scientist, 57 (11), pp. 1623-1642.

14. Kamiński J. (2011), Istota i etapy rozwoju marketingu terytorialnego, Studia Ekonomiczne i Regionalne, IV (1).

15. Kavaratzis M. (2004), From city marketing to city branding: towards a theoretical framework for developing city brands, Place Branding, 1 (1), pp. 58-73.

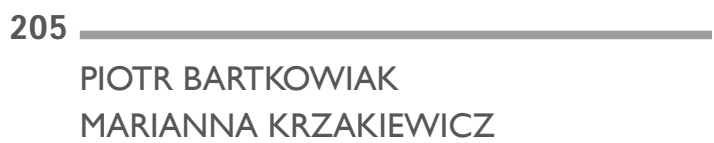


16. Lehmann A. (2017), Wyborcza.pl, Poznań. Czy Poznańjest przyjazny starzeniu? http:// poznan.wyborcza.pl/poznan/7,36001,22446359,poznanprzyjazny-starzeniu.html? disableRedirects=true (30.09.2017 - access date).

17. Melissen J. (2005), The New Public Diplomacy. Soft Power in International Relations, Houndmills, Palgrave Macmillan, New York.

18. Morais P., Miguéis V. L., Camanho A. S. (2011). Quality of Life Experienced by Human Capital: An Assessment of European Cities, Social Indicators Research, pp. 187-206.

19. Nakamura T. (2013), Japan's New Public Diplomacy, Coolness in Foreign Policy Objectives.

20. Nye J. (1990), Bound to Lead: The changing nature of American power, Basic Books, New York.

21. Poznan City Council (2009), Uchwata nr LXIV/898/V/2009 Rady Miasta Poznania z dnia 8 grudnia 2009 r. w sprawie utworzenia Centrum Inicjatyw Senioralnych, Poznan.

22. Poznan, Statistical Bulletin (2016), Statistical Office in Poznan, Poznań.

23. Poznan, Statistical Bulletin (2017), Statistical Office in Poznan, Poznań.

24. Ross C. (2003), Pillars of Public Diplomacy. Grappling with International Public Opinion, Harvard International Review, pp. 22-27.

25. Rowerowa przygoda nad Strzeszynkiem! (2017), www.poznan.pl/mim/wos/ news/rowerowa-przygoda-nad-strzeszynkiem,110412.html (12.02.2018 access date).

26. Snow N. (2010), Public diplomacy. New dimensions and implications, [in:] T. L. McPhail, Global communication. Theories, stakeholders and trends, Wiley-Blackwell, Chichester, pp. 84-102.

27. Stępowski R. (2017), Wydatki i działania promocyjne polskich miast i regionów, Ed. ROSTER, Warszawa.

28. Szkutnik Z. (2017), Moodle na ustugach Rad Seniorów, http://mrs.poznan. $\mathrm{pl} /$ moodle-na-uslugach-rad-seniorow/ (15.11.2017 - access date).

29. Szromnik A. (2011), Marketing terytorialny jako atrybut rynkowej orientacji miast oraz regionów, [in] A. Grzegorczyk, A. Kochaniec, Kreowanie wizerunku miast, Ed. Wyższa Szkoła Promocji, Warszawa, (pp. 18-41).

30. Szromnik A. (2016), Marketing terytorialny. Miasto i region na rynku, Wolters Kluwer, Warszawa.

31. Taecharungroj V. (2016), City ambassadorship and citizenship behaviours. Modelling resident behaviours that help cities grow, Journal of Place Management and Development, 9 (3), pp. 331-350.

32. von Hoffen L. P., Säumel I. (2014), Orchards for edible cities: Cadmium and lead content in nuts, berries, pome and stone fruits harvested within the inner city neighbourhoods in Berlin, Germany, Ecotoxicology and Environmental Safety, pp. 233-239. 
33. Www.vivaseniorzy.pl/pl/o_targach/dlaczego_warto/ (12.02.2018 access date).

34. Wyrwa J. (2015), Marketingowe aspekty funkcjonowania jednostki samorzadu terytorialnego, Zeszyty Naukowe Polskiego Towarzystwa Ekonomicznego w Zielonej Górze (3), pp. 17-35.

35. Zambianchi, M., \& Carelli, M. (2016, May). Positive Attitudes towards Technologies and facets of Well-being in Older Adults. Journal for Applied Gerontolology.

36. Zbuchea, A. (2014). Territorial Marketing Based on Cultural Heritage. Management \& Marketing, XII (2), pp. 135-151. 